\title{
Correlations between Listening Comprehension Problems Encountered By English Majors and Their Coping Strategies
}

\author{
Chau Thanh Nha, M.A. ${ }^{1}$, Hoang Thi Hoa, M.A. ${ }^{2}$ \\ Van Lang University, Vietnam
}

*Corresponding Authors: Chau Thanh Nha, M.A., Van Lang University, Vietnam

\begin{abstract}
Listening is considered one of the most significant macro skills in the process of language acquisition. In EFL classrooms, however, this skill is likely to be underemphasized, which may cause EFL learners confusion and difficulties in comprehending what people intend to express. The difference between effective listeners and ineffective listeners has been showed clearly through the employment of the learning strategies. Learners with higher level of proficiency in listening were the ones who have employed more various strategies than those who have not used the strategies very often. Therefore, the present study aimed to investigate the correlations between the listening problems and strategy usage among English majors at the Saigon International University. The quantitative study was conducted with the participation of 115 undergraduate students majoring in English. The quantitative data collected from the questionnaire were processed by SPSS (19.0). The study found out some positive and significant correlations between the listening problems and strategies. It is recommended that more studies on correlations between listening problems and solutions. Last but not least, the similarities and differences in perception of listening difficulties and solutions should be conducted in which different instruments should be employed for data collection.
\end{abstract}

Keywords: correlations, listening comprehension problems, coping strategies, Vietnamese EFL context

List of abbreviations: EFL: English as a Foreign Language, SIU: The Saigon International University

\section{INTRODUCTION}

Listening, one of the two receptive skills, plays an essential role in foreign language learning. The more the language learners listen, the more they are exposed to the target language and that leads to the language acquisition (Peterson, 2001). According to Morley (1999), listening serves a dominant role compared to reading, the other receptive skill, because it is the most frequently utilized language skill. In addition, Rost (2002) points out that proficiency in speaking will be resulted from proficiency in listening.

Osada (2004) and Sharma (2007) proved that one of the distinctive features classifying successful listeners from unsuccessful ones is their employment of listening strategies. It is conclusive that analyzing the relationship between the listening strategies and the listening problems could help learners approach the listening tasks more successfully.

The recent studies have separately discovered the listening comprehension problems and the strategies employed by the listeners. More worthily, they have not focused on the correlations between each specific difficulty and a particular strategy that could be used to sidestep that problem.

In the context of Vietnam, students have been encountering a lot of difficulties in learning listening comprehension because other skills such as speaking, reading and writing have been more focused to be taught to the students than listening at universities or schools (To, 2006). What is more, students have not figured out the strategies that are effective in helping them get round their ongoing problems. Therefore, the authors wanted to carry out a study in the hope of shedding new light on the sound strategies towards the perceived problems. One research question was formulated as follows.

Research question: Are there any correlations between English listening comprehension problems and English listening learning strategies? If so, how?

International Journal on Studies in English Language and Literature (IJSELL) 


\section{AIMS AND OBJECTIVES OF THE STUDY}

Based on the aforementioned reasons, the authors conducted the study to find out the answers whether there are some correlations between English listening comprehension problems and English listening learning strategies employed by English Majors at the Saigon International University (hereafter SIU) and if yes, how positively and significantly they are correlated.

\section{LITERATURE REVIEW}

\subsection{Listening Comprehension Problems}

Ur (1984) analyses some factors that may inhibit learners' listening comprehension and lists them in order according to the importance: (a) sounds, (b) intonation and stress, (c) coping with redundancy and noise, (d) predicting, (e) colloquial vocabulary, (f) fatigue, (g) different accents, (h) visual and aural environmental clues. Richards (1983) has some listening factors causing listening problems in common with Ur's (1984), but still has some different conclusions regarding nine medium factors that can affect considerably how messages are understood. These medium factors are: (a) clausal basic of speech, (b) reductions of forms, (c) ungrammatical forms, (d) pausing and speech errors, (e) rate of speech delivery, (f) rhythm and stress, (g) cohesive devices, and (h) information content.

\subsection{Listening Strategies}

\subsubsection{Cognitive Strategies}

Derry and Murphy (1986) state that cognitive strategy is a problem-solving method employed by the leaners in order to gain the knowledge and skills. Richards (2008, p. 11) identifies cognitive strategies as "mental activities related to comprehending and storing input in working memory or long-term memory for later retrieval" including:

- Comprehension processes: related to the processing of linguistic and non-linguistic input

- Storing and memory processes: related to the retention of linguistic and non-linguistic input in working memory and long-term memory

- Using and retrieval processes: related to getting accessed to memory, to be prepared for output.

\subsubsection{Metacognitive Strategies}

Richards (2008. p. 11) clearly identifies metacognitive strategies as "conscious and unconscious activities that perform an executive function in the management of cognitive strategies" including:

- Assessing the situation: Thinking carefully of the situation from a language task by checking listeners' own knowledge, listeners' available internal and external resources as well as the restrictions of the situations before taking part in a task

- Monitoring: Checking the effectiveness of the listener's own performance and another listener's while engaged in a task

- Self-evaluating: Checking the effectiveness of the listener's own performance and another listener's after taking part in a task

- Self-testing: Testing the listener himself to check the effectiveness of his own language use or the lack thereof.

\subsubsection{Socio-Affective Strategies}

Cross (2009), Vandergrift (2003, 1997), Chamot (2005), and Oxford (1990) identify socio-affective strategies as the process of employing the three following strategies:

- Cooperation strategy: listeners work with friends to complete a listening task and check the accuracy together.

- Question-for-clarification strategy: listeners ask their teachers or friends for explanation, clarification as well as feedback on what they have done with the listening task.

- Self-motivation strategy: listeners get some ways to relieve anxiety and encourage and remind themselves of making progress. 


\subsection{The Effects of Listening Learning Strategies on Listening Comprehension Performance}

Some researchers have endeavored to learn about the relationship between listening strategies and listening outcomes. The findings of their studies have set the theoretical and scientific foundations which have demonstrated the significance of learning strategies in improving the level of proficiency in listening comprehension. Leaners can adopt this strategy to help them process, retain and digest the new information (Goh, 1998). Aneiro (1989) confirms that low anxiety and high listening performance are much connected with each other, i.e. listeners employing socio-affective strategies can easily reduce apprehension and better listening.

Yildiz and Albay (2015), who studied the factors affecting listening comprehension and strategies for improvement, suggested some listening learning strategies. Regarding the cognitive listening strategies, listeners needed to possess great knowledge about linguistics because they could not comprehend the listening text if their knowledge of grammar, vocabulary, pronunciation, etc. was limited. Regarding the metacognitive listening strategies, the chosen topics must be interesting enough to motivate the students to produce good performance on the listening task. Next, speed of delivery had to be slower than the normal speech. Listeners could not understand and lost concentration if the speakers spoke very fast. In addition, native accents should be chosen because the accents of the speakers have had strong influences on the understanding of the text. Finally, listening environment was an important factor affecting the effectiveness of listening. Therefore, it should be silent and motivating.

In addition to offering the strategies for students to better listening comprehension, teachers should be also provided with listening teaching strategies to help them improve their teaching and support the students as well. As suggested by Gilakjani and Sabouri (2016), teachers were expected to apply more metacognitive strategies than the others. With regard to metacognitive strategies, teachers should understand students' needs so that they could choose the appropriate authentic materials including interesting listening topics from different kinds of input for students to practice. Moreover, different types of listening tasks should be introduced to students because one listening task had its own features and needed different techniques to be completed perfectly. Concerning cognitive strategies, teachers were expected to help students to get familiar to the different accents, pronunciation, to widen their contextual and linguistic knowledge. In terms of socio-affective strategies, feedback or clarification should be given and motivation should be provided on the spot in order to encourage students to perform better.

Simasangyaporn (2016) learned about the effect of listening strategy instruction on Thai learners' self-efficacy, English listening comprehension and reported use of listening strategies. The study was conducted with the participation of 116 Thai undergraduate EFL students to check if the program of listening strategy instruction in terms of metacognitive, cognitive and socio-affective strategies could improve the students' level of self-efficacy, level of listening comprehension, and reported use of the strategies, and to evaluate if the students with different levels could benefit from the strategy instruction in the same manner. The most remarkable finding was that the listening strategy instruction could improve outstandingly the level of proficiency in listening.

Not many learners have employed the listening strategies while listening or even they have sometimes applied one or two types of strategies. For example, Bao (2017) studied the listening strategies instructed by teachers and strategies employed by learners. The results showed that students tended to use cognitive strategies more than the others and even did not use socio-affective strategies at all, whereas teachers preferred using metacognitive strategies.

The finding in the study of Goh (2002) showed that an effective listener employed both cognitive and metacognitive strategies to achieve a complete understanding of the listening text, and had the ability to use prior knowledge, linguistic cues and contextual information whereas an unskilled listener was often distracted by unfamiliar words and used only low-level comprehension strategies.

The role of metacognitive awareness in students' learning outcomes and their achievement in different school subjects has been focused in many studies. The findings showed an extensive evidence that students' learning outcomes and learning process could be directly affected by their metacognition

(Boekaerts, Pintrich, \& Zeidner, 2000; Eilam \& Aharon, 2003; Mokhtari \& Reichard, 2002; Palmer \& Goetz, 1988; Victori \& Lockhart, 1995; Zimmerman \& Schunk, 2001). 


\section{RESEARCH METHODOLOGY}

\subsection{Research Design}

The quantitative research approach was employed in the present study. Concerning the quantitative research method, according Bryman (2001), the quantitative research method focuses on the work with numbers or figures in data collection and analysis and can be regarded as being scientific in nature. This research method is more connected to the objectivities and validities of what has been observed or surveyed. The size of the involved sample is often large (Babbie, 1989; Bogdan \& Biklen, 1992). An important factor of this research method is that both descriptive and analytical summaries can be combined in the process of data collection (Smith, 1994). The hypotheses and theories of the studies are tested with the use of the qualitative research.

\subsection{Research Setting}

This study was conducted at The Saigon International University (SIU) at \#8C\&16C, Tong Huu Dinh Street, Thao Dien Ward, District 2, Ho Chi Minh City, Vietnam. In case of SIU, a young university with the total number of 115 students majoring in English language, the students study the four English skills throughout the four years at university.

\subsection{Sample and Sampling Procedures}

The convenience sampling strategy was employed in this study because it concerns "a group of individuals that is ready and available" (Fink, 1995, p. 67). Therefore, the authors could select the participants easily and conveniently. Moreover, the authors used to be in-service lecturers at SIU, so they were allowed to conduct the study. In addition, it took the participants only about fifteen minutes to answer the questionnaire, so the students were willing to participate in the survey.

The participants in the present study consisted of 115 English majors (44 males and 71 females) from School of Foreign Languages. The reason for choosing all of the students was because there are not many students of English at SIU, 115 in total, 19 fourth-year students, 24 third-year students, 40 second-year students and 32 first-year students, if choosing only one, two or even three courses, the data obtained would not be reliable enough and the results might be meaningless. Thus, that all the students participated in the study was the best choice.

Moreover, their age ranged from eighteen to twenty-five. In addition, $51 \%$ of the participants spent from fifteen to one hour per day learning listening comprehension after school, whereas there were $13 \%$ of students spending one hour and a half to three hours and a half, $8 \%$ of students spending more than three hours and a half, and $28 \%$ of students stating that it depended on their free time. The time students have spent on listening practices.

\subsection{Research Instrument}

Most data in quantitative research can be collected by means of questionnaires (Smith, 1994). Bell (2003) points out that a questionnaire is essentially considered a structured approach for collecting primary data. Therefore, a series of questions is prepared to get the answers from the respondents. Large amounts of information can be collected from many people in a short period of time (Ackroyd \& Hughes, 1981). It is also believed to be one of the best ways to collect quantitative data (Ackroyd \& Hughes, 1981).

The questionnaire in the present study was adapted from three studies: the study of Thai Cong Dan and Nguyen Ngoc Quyen's (2017), Bao's (2017), and Simasangyaporn's (2016). The reason for this choice was because the author has realized that the questionnaires employed in these studies have had most of the features in common with the related literature that the author reviewed. Hence, the questionnaire was used to collect quantitative data on students' perspectives on problems of English listening comprehension and learning strategies that they have employed to solve the problems.

The questionnaire of this study consisted of three parts. In Part I, the participants were asked to provide their demographics by answering the first four questions about genders, age range, academic year and time for listening. Part II focused on the participants' perspectives on English listening comprehension problems related to the listening text, the speaker, the listener and the physical setting. Part III focused on participants' perspectives on listening strategies that they have employed to solve the problems mentioned in Part II. In order to answer the Part II and III, the participants were asked to 
choose the appropriate level for five close-ended items designed in 5-point Likert scale $(1=$ never, $2=$ rarely, 3 = sometimes, 4 = often, 5 = always).

\subsection{Data Collection and Analysis Procedures}

The questionnaire in Vietnamese was administered to 115 English majors during the class time in about fifteen minutes without any preparation. The participants answered the questionnaire with the support from the teacher researcher for any clarifications. The data obtained from the questionnaire were analyzed by means of SPSS 19.0 in which a Pearson's correlation was run to determine the linear relationships between English listening comprehension problems and listening learning strategies.

\subsection{Validity and Reliability}

To increase the reliability and validity of the questionnaire, it had been written first in English and then translated into Vietnamese to help the participants understand the items in the questionnaire better, just in case, some participants were not proficient in English. Moreover, the English version was checked by an expert for the validity of the content, and the Vietnamese version was crosschecked by two Vietnamese lecturers of English, one works at Industrial University of Ho Chi Minh City, and the other is the author's colleague, for the accuracy of the translation. More importantly, piloting the questions contributes to enhance the quality of the questionnaire because it is proved that the reliability, validity and practicality of the research instruments can be increased through a pilot study (Oppenheim, 1992; Radhakrishna, 2007; Seliger \& Shohamy, 1997). Therefore, before officially administering the questionnaire to the participants, it was piloted with the participation of 21 English majors to check how well they understood the content of the translated version. Fortunately, the questionnaire was well-understood by all the participants, and there were no corrections or modifications then. More worthily, the reliability of the questionnaire was quantitatively computed by SPSS. The Cronbach's Alpha coefficients used in the present study to measure the reliability were set by George and Mallery (2003) including unacceptable: $\alpha<0.500$; poor: $0.500 \leq \alpha<0.600$; questionable: $0.600 \leq \alpha<0.700$; acceptable: $0.700 \leq \alpha<0.800$; good: $0.800 \leq \alpha<0.900$; and excellent: $0.900 \leq \alpha$. The second and third sections of the questionnaire were measured separately. The second section included 22 items regarding problems of English listening comprehension. The reliability result, quantitatively computed by SPSS, was .87, as presented in Table 1.

Table1. Reliability Statistics on the Items Regarding ELC Problems for the Main Study

\begin{tabular}{|c|c|}
\hline Cronbach's Alpha & N of Items \\
\hline .87 & 22 \\
\hline
\end{tabular}

The third section of the questionnaire consisted of 17 items regarding the listening learning strategies. The reliability result, quantitatively computed by SPSS, was .77, as presented in Table 2.

Table2. Reliability Statistics on the Items Regarding Listening Strategies for the Main Study

\begin{tabular}{|c|c|}
\hline Cronbach's Alpha & N of Items \\
\hline .77 & 17 \\
\hline
\end{tabular}

In conclusion, the results of reliability statistics represented in Table 1 and Table 2, specifically .87 for the items regarding the ELC problems and .77 for items regarding the listening learning strategies, have showed that the questionnaire was reliable enough to be used for collecting data.

\section{FINDINGS AND DISCUSSION}

\subsection{Findings}

Based on the data amassed from the questionnaire, a Pearson's correlation was run by SPSS (19.0) to determine the linear relationship between English listening comprehension problems and listening learning strategies. The strength of the relationship is denoted by $\mathrm{r}$ as " $-1 \leq \mathrm{r} \leq 1$ ". The closer the value is to 1 or -1 , the stronger the linear correlation is. Moreover, "-1" means negative correlation, whereas " 1 " means positive correlation. Besides, a significance test was taken in order to decide if there was any or no evidence suggesting that a significant linear correlation was present in the population. The result of the significance test was represented by the $p$-value. If the p-value equals 0 $(\mathrm{p}=0)$, there is no correlation present in the population; if not, the correlation in the population is present (Robin, 2012). 
Correlations between Listening Comprehension Problems Encountered By English Majors and Their Coping Strategies

\subsubsection{The Correlation between Problems Related to the Listening Text and Metacognitive Strategies}

The calculation of Pearson's correlation coefficient together with subsequent significance testing was done in order to discover if there was any relationship among the variables which belonged to the groups of listening problems related to the listening text and metacognitive strategies. The correlation output produced from SPSS was presented in Table 3 as follows.

Table3. Correlation between Problems Related to the Listening Text and Metacognitive Strategies

\begin{tabular}{|c|c|c|c|c|c|c|c|c|}
\hline \multirow{9}{*}{ 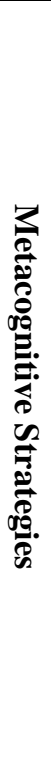 } & \multirow{3}{*}{\multicolumn{2}{|c|}{ Items }} & \multicolumn{6}{|c|}{ Problems related to the listening text } \\
\hline & & & & $\mathrm{a}$ & $\mathrm{b}$ & $\mathrm{c}$ & $\mathrm{d}$ & $\mathrm{e}$ \\
\hline & & & & $\begin{array}{l}\text { Unfamiliar } \\
\text { words }\end{array}$ & $\begin{array}{l}\text { Complex } \\
\text { sentence } \\
\text { structures }\end{array}$ & $\begin{array}{c}\text { Slang, } \\
\text { idioms and } \\
\text { colloquial }\end{array}$ & $\begin{array}{l}\text { Unfamiliar } \\
\text { listening } \\
\text { topic }\end{array}$ & $\begin{array}{c}\text { Long } \\
\text { listening } \\
\text { text }\end{array}$ \\
\hline & 1 & Have a plan & $\begin{array}{l}\mathrm{r} \\
\mathrm{p}\end{array}$ & $\begin{array}{l}.050 \\
.594\end{array}$ & $\begin{array}{l}-.056 \\
.552\end{array}$ & $\begin{array}{l}.076 \\
.418\end{array}$ & $\begin{array}{l}.052 \\
.579\end{array}$ & $\begin{array}{l}.013 \\
.893\end{array}$ \\
\hline & 2 & $\begin{array}{l}\text { Suitable listening } \\
\text { text }\end{array}$ & $\begin{array}{l}\mathrm{r} \\
\mathrm{p}\end{array}$ & $\begin{array}{c}.326 * * \\
.000\end{array}$ & $\begin{array}{l}.200 * \\
.032\end{array}$ & $\begin{array}{l}.094 \\
.320\end{array}$ & $\begin{array}{l}.167 \\
.075\end{array}$ & $\begin{array}{l}.192 * \\
.040\end{array}$ \\
\hline & 3 & $\begin{array}{l}\text { Read the audio } \\
\text { scripts for } \\
\text { unfamiliar words }\end{array}$ & $\begin{array}{l}\mathrm{r} \\
\mathrm{p}\end{array}$ & $\begin{array}{c}.265 * * \\
.004\end{array}$ & $\begin{array}{l}.151 \\
.108\end{array}$ & $\begin{array}{l}.024 \\
.803\end{array}$ & $\begin{array}{l}.080 \\
.393\end{array}$ & $\begin{array}{l}.047 \\
.621\end{array}$ \\
\hline & 4 & $\begin{array}{l}\text { Listen to different } \\
\text { accents }\end{array}$ & $\begin{array}{l}\mathrm{r} \\
\mathrm{p}\end{array}$ & $\begin{array}{l}-.023 \\
.803\end{array}$ & $\begin{array}{l}-.083 \\
.379\end{array}$ & $\begin{array}{l}-.095 \\
.311\end{array}$ & $\begin{array}{l}-.075 \\
.426\end{array}$ & $\begin{array}{l}-.005 \\
.962\end{array}$ \\
\hline & 5 & $\begin{array}{l}\text { Review the } \\
\text { listening materials }\end{array}$ & $\begin{array}{l}\mathrm{r} \\
\mathrm{p}\end{array}$ & $\begin{array}{l}.199 * \\
.033\end{array}$ & $\begin{array}{l}.071 \\
.450\end{array}$ & $\begin{array}{l}.079 \\
.401\end{array}$ & $\begin{array}{l}.118 \\
.210\end{array}$ & $\begin{array}{l}.078 \\
.406\end{array}$ \\
\hline & 6 & $\begin{array}{l}\text { Evaluate what has } \\
\text { been done }\end{array}$ & $\begin{array}{l}\mathrm{r} \\
\mathrm{p}\end{array}$ & $\begin{array}{l}.086 \\
.359\end{array}$ & $\begin{array}{l}.076 \\
.418\end{array}$ & $\begin{array}{l}-.045 \\
.631\end{array}$ & $\begin{array}{c}-.020 \\
.829\end{array}$ & $\begin{array}{l}-.129 \\
.169\end{array}$ \\
\hline
\end{tabular}

As can be seen in Table 3, there were some positive correlations between paired variables belonged to groups of listening problems and metacognitive strategies. Specifically, there was a positive correlation between strategy 2 and listening problem marked item a $(\mathrm{r}=.326, \mathrm{p}=.000)$. This can be explained that the strategy of choosing the listening texts which were not beyond the listener's ability could solve the problem of coming across unfamiliar words. In addition, this strategy also had other positive correlations with the two other listening problems labeled item $b$ and item e. First, for the correlation with the listening problem marked item $b$, the Pearson correlation coefficient value of $r=$ .200 , together with the p-value as being .032 confirmed a positive correlation between two variables. This means that in order not to come across the complex sentence structures, students tended to choose the materials that were not beyond their ability. Next, with the coefficient value of $r=.192$ and the significance value of $\mathrm{p}=.040$, the present strategy and listening problem marked item e were positively correlated. In more detail, a number of students did not have the ability to listen to long listening texts since they made them confused and tired, many of them chose the texts that were long enough to listen.

Besides, a positive correlation was also discovered between the listening problem marked item a and the metacognitive strategy marked item $3(\mathrm{r}=.265, \mathrm{p}=.004)$. This means that students read the audio scripts for unfamiliar words and consulted dictionaries for meaning and pronunciation.

Finally, Table 3 also shows another positive correlation between the listening problem marked item a and the metacognitive strategy marked item $5(\mathrm{r}=.199, \mathrm{p}=.033)$. It can be explained that reviewing the materials helped students get to know unfamiliar words that they had come across while learning listening in class.

\subsubsection{The Correlation Between Problems Related to the Listening Text and Cognitive Strategies}

The calculation of Pearson's correlation coefficient, together with subsequent significance testing was done in order to discover if there was any relationship among the variables which belonged to the groups of listening problems related to the listening text and cognitive strategies. The correlation output produced from SPSS was presented in Table 4 as follows. 
Correlations between Listening Comprehension Problems Encountered By English Majors and Their Coping Strategies

Table4. Correlation Between Problems Related to the Listening Text and Cognitive Strategies.

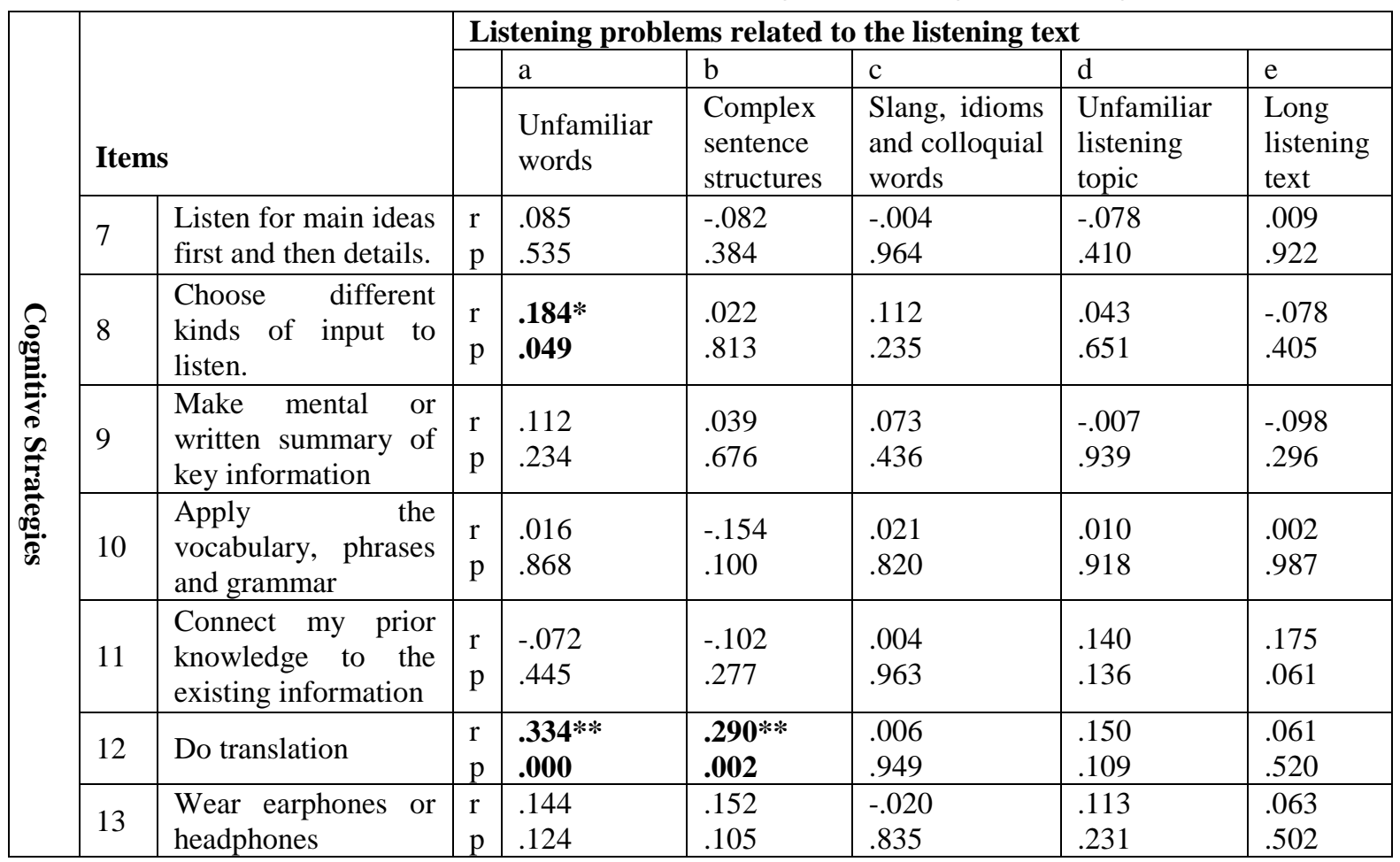

As illustrated in Table 4, there were three positive correlations between the listening problems related to listening text and cognitive strategies as follows:

First, there was a positive correlation between the listening problem marked item a and the cognitive strategy marked item $8(\mathrm{r}=.184, \mathrm{p}=.049)$. Conclusively, practicing listening using different kinds of input such as lectures, radio news, songs, films, etc. was a useful strategy to enrich vocabulary.

Next, as showed in Table 2 that there were two more positive correlations between the cognitive strategy marked item 12 and the two listening problems marked items a and b. For the first correlation, the pretty high coefficient value of $r=.334$ indicated that the cognitive strategy and the listening problem marked item a were positively and significantly correlated $(\mathrm{r}=.334, \mathrm{p}=.000)$. The latter remarkable correlation with the pretty high coefficient value of $r=.290$ as well as the $p$-value of .002 existed between this cognitive strategy and the listening problem marked item $\mathrm{b}$. In other words, when students came across unfamiliar words or even complex sentence structures, translation was the best solution to be employed in this case.

\subsubsection{The Correlation Between Problems Related to the Listening Text and Socio-Affective Strategies}

The calculation of Pearson's correlation coefficient, along with subsequent significance testing was done in order to discover if there was any relationship among the variables which belonged to the group of problems related to the listening text and socio-affective strategies. The correlation output produced from SPSS was presented in Table 5 as follows.

Table5. Correlation between Problems Related to the Listening Text and Socio-Affective Strategies.

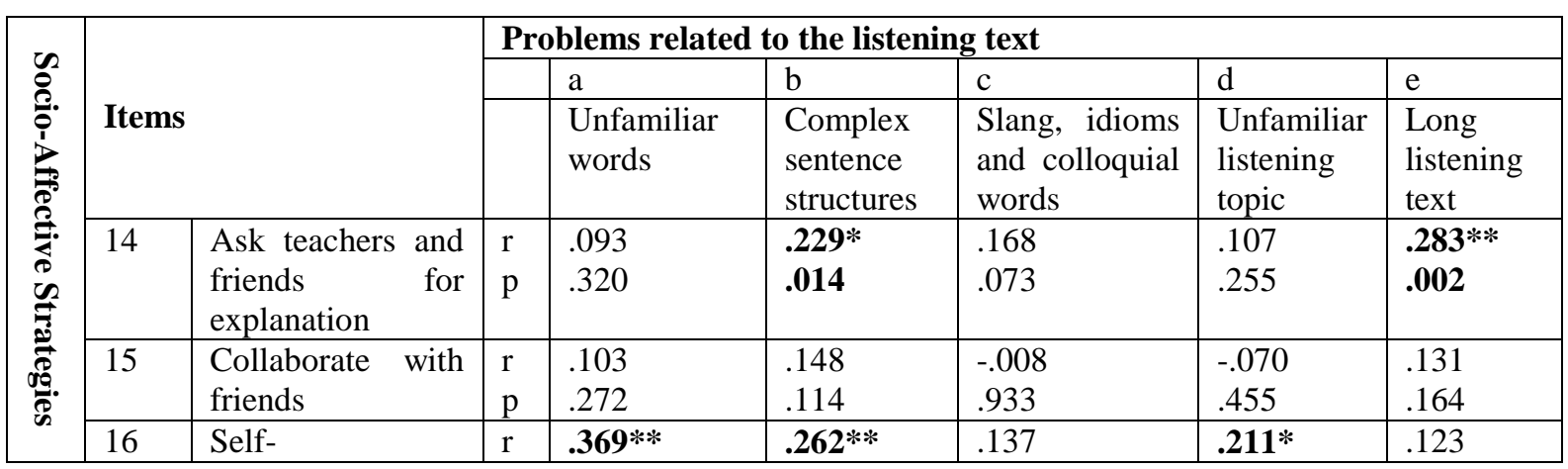


Correlations between Listening Comprehension Problems Encountered By English Majors and Their Coping Strategies

\begin{tabular}{|l|l|l|l|l|l|l|l|l|}
\hline & & encouragement & $\mathrm{p}$ & $\mathbf{. 0 0 0}$ & $\mathbf{. 0 0 5}$ & .145 & $\mathbf{. 0 2 4}$ & .191 \\
\cline { 2 - 9 } & \multirow{2}{*}{ Self-rewarding } & $\mathrm{r}$ & .172 & .150 & -.052 & -.003 & -.035 \\
& & $\mathrm{p}$ & .066 & .108 & .581 & .974 & .707 \\
\hline
\end{tabular}

According to Table 5, there were five significant correlations existing between the listening problems and the socio-affective strategies as follows.

When students came across the listening problem regarding complex sentence structures while listening (item b), they asked for explanation or verification from the teachers or peers (item 14). These two variables were positively correlated $(\mathrm{r}=.229, \mathrm{p}=.014)$. Moreover, asking for help from teachers or friends was also employed when students suffered the too long listening text (item e). The coefficient values of $r=.283$ and $p=.002$ showed a close correlation between these two variables.

Next, the socio-affective strategy marked item 16 had the correlations with three listening problems marked items a, b, and d. First, the high coefficient value of $r=.369$ along with the $p$-value of .000 revealed the remarkable correlation between the listening problem marked item a and the present listening strategy. In a same vein, a positive correlation also existed between this strategy and the listening problem marked item $\mathrm{b}(\mathrm{r}=.262, \mathrm{p}=.005)$. What is more, this socio-affective strategy and the listening problem marked item $\mathrm{d}$ were well-correlated $(\mathrm{r}=.211, \mathrm{p}=.024)$. In brief, selfencouragement effectively helped listeners to try to overcome the difficulties.

\subsubsection{The Correlation between Problems Related to the Speaker and Metacognitive Strategies}

The calculation of Pearson's correlation coefficient as well as subsequent significance testing was done in order to discover if there was any relationship among the variables which belonged to the groups of problems related to the speaker and metacognitive strategies. The correlation output produced from SPSS is presented in Table 6 as follows.

Table6. Correlation between Problems Related to the Speaker and Metacognitive Strategies

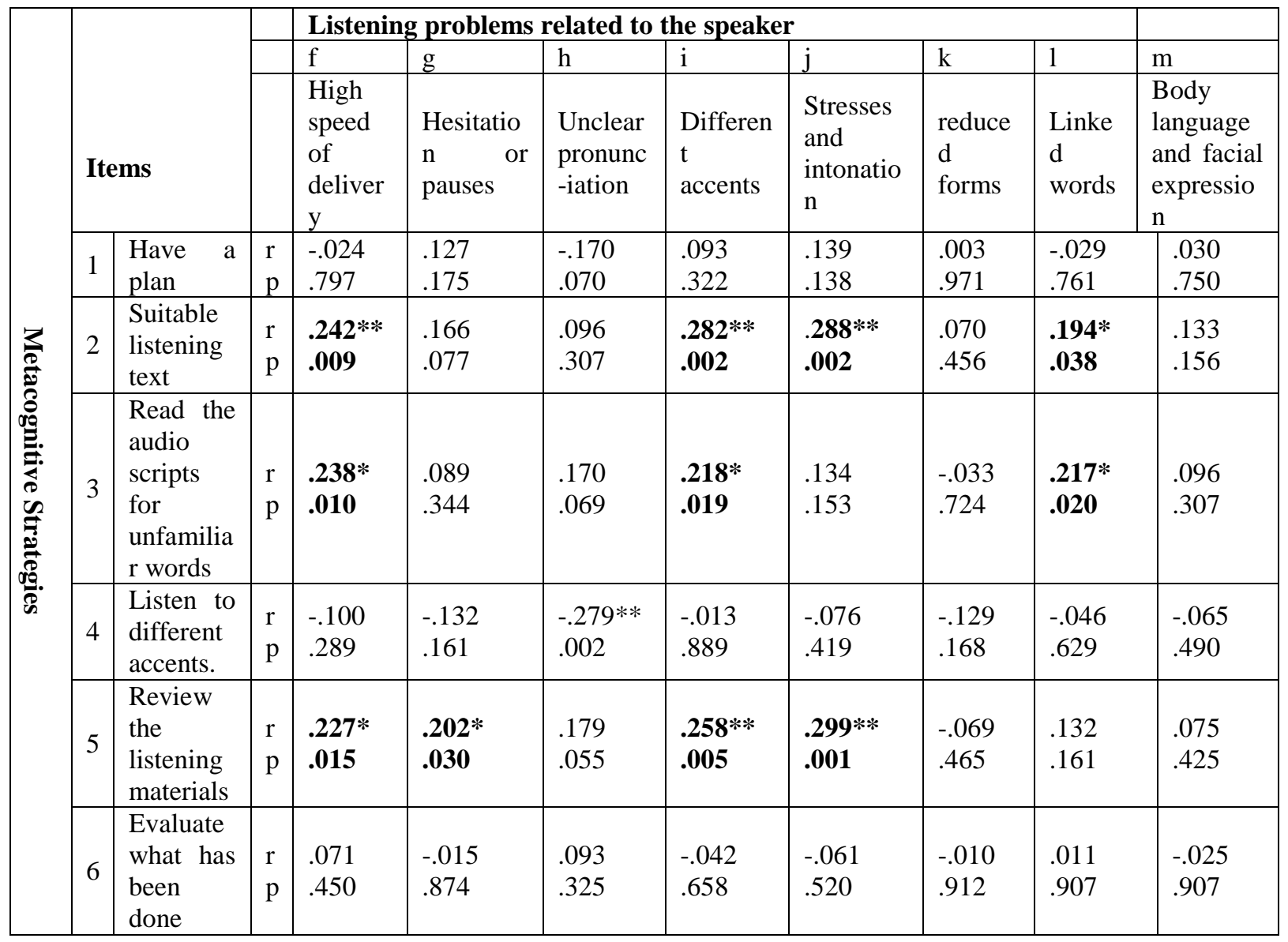

According to Table 6 , there were four positive correlations between a metacognitive strategy labeled item 2 and the four different listening problems related to the speaker labeled items f, $\mathrm{i}, \mathrm{j}$ and 1 . The 
first positive and significant correlation was between the present metacognitive strategy and the listening problem marked item $\mathrm{f}(\mathrm{r}=.242, \mathrm{p}=.009)$. In other words, choosing the listening texts which were not beyond students' ability prevented them from suffering high speed of delivery. The second correlation existed between this metacognitive strategy and the listening problem marked item $\mathrm{i}(\mathrm{r}=.282, \mathrm{p}=.002)$. A close relationship existing between these two variables showed that choosing suitable listening materials would help students get familiar to different accents of the speaker gradually. Next, the pretty high correlation coefficient value of $r=.288$ and the significance test result of $\mathrm{p}=.002$ demonstrated the third good correlation of the metacognitive strategy with the listening problem marked item j, i.e. choosing appropriate listening materials helped listeners avoid linguistic barriers in terms of stress and intonation and make progress deliberately. Last but not least, this strategy and the listening problem marked item 1 were the final paired variables that had the positive correlation $(\mathrm{r}=.194, \mathrm{p}=.038)$. Particularly, when listeners chose the listening materials not beyond their ability, they could not have the problems of words that were linked together made by the speaker.

In addition, Table 6also shows three more correlations between the metacognitive strategy marked item 3 and three different listening problems marked Items $f$, $i$, and 1 . The coefficient value of $r=$ .238 , together with the p-value of .010 indicated a close correlation of the present strategy and the listening problem marked item f. Specifically, when the speakers spoke to fast, one of the best strategies was to read the audio scripts to follow the speakers' speed and understand the content. In addition, different accents produced by the speakers caused the listener confusion, so in order to understand the content and gradually get familiar with different accents, many participants chose to read the audio scripts. This explanation revealed another positive correlation between the present metacognitive strategy and the listening problem marked item i $(r=.218, p=.019)$. Lastly, one more positive correlation was also present between the present strategy and the listening problem marked item $1(\mathrm{r}=.217, \mathrm{p}=.020)$. More clearly, when students could not recognize the words because the speakers linked them together, they solved this problem by reading the audio scripts to understand what was expressed or implied.

The last group of correlation showed in Table 6 was between the metacognitive strategy marked item 5 and four different listening problems marked items $\mathrm{f}, \mathrm{g}, \mathrm{i}$, and $\mathrm{j}$. By reviewing the listening texts in a planned way after class, listeners were able to solve the problem of high speed of delivery. The interpretation supported a positive correlation between the present strategy and the listening problem marked item $\mathrm{f}(\mathrm{r}=.227, \mathrm{p}=.015)$. In addition, this strategy could help students to sidestep the problem of the speakers' hesitation or pauses because when they practiced a lot, they might deal with many problems arisen. This explained another positive correlation of the present strategy with the listening problem marked item $\mathrm{g}(\mathrm{r}=.202, \mathrm{p}=.030)$. Moreover, the correlation coefficient value of $\mathrm{r}$ $=.258$ as well as the p-value of .005 demonstrated one more close relationship between the present solution of reviewing the listening materials in a planned way after class and different accents produced by the speakers (item i), i.e. students were able to get familiar with a particular accent if they listened to that accent repeatedly and in a planned way. Finally, the present strategy was also considered an effective solution to the listening problem labeled item $\mathrm{j}$. Participants could deal with every language or linguistic barrier when they practiced regularly $(\mathrm{r}=.299, \mathrm{p}=.001)$.

\subsubsection{The Correlation Between Problems Related to the Speaker and Cognitive Strategies}

The calculation of Pearson's correlation coefficient together with subsequent significance testing was done in order to discover if there was any relationship among the variables which belonged to the group of problems related to the speaker and cognitive strategies. The correlation output produced from SPSS was presented in Table 7 as follows.

Table7. Correlation between Problems Related to the Speaker and Cognitive Strategies.

\begin{tabular}{|c|c|c|c|c|c|c|c|c|c|}
\hline \multirow[b]{3}{*}{ 呑 } & \multirow[b]{3}{*}{ Items } & \multicolumn{7}{|c|}{ Listening problems related to the speaker } & \multirow[b]{2}{*}{$\mathrm{m}$} \\
\hline & & $\mathrm{f}$ & $\mathrm{g}$ & $\mathrm{h}$ & $\mathrm{i}$ & $\mathrm{j}$ & $\mathrm{k}$ & 1 & \\
\hline & & $\begin{array}{l}\text { High } \\
\text { speed } \\
\text { of } \\
\text { deliver } \\
\text { y. }\end{array}$ & $\begin{array}{l}\text { Hesitatio } \\
\mathrm{n} \quad \text { or } \\
\text { pauses. }\end{array}$ & $\begin{array}{l}\text { Unclea } \\
\mathrm{r} \\
\text { pronun } \\
- \\
\text { ciation }\end{array}$ & $\begin{array}{l}\text { Differe } \\
\text { nt } \\
\text { accents. }\end{array}$ & $\begin{array}{l}\text { Stresses } \\
\text { and } \\
\text { intonatio } \\
n\end{array}$ & $\begin{array}{l}\text { reduce } \\
d \\
\text { forms }\end{array}$ & $\begin{array}{l}\text { Linke } \\
\text { d } \\
\text { words }\end{array}$ & $\begin{array}{l}\text { Body } \\
\text { language } \\
\text { and facial } \\
\text { expressio } \\
\text { n. }\end{array}$ \\
\hline
\end{tabular}


Correlations between Listening Comprehension Problems Encountered By English Majors and Their Coping Strategies

\begin{tabular}{|c|c|c|c|c|c|c|c|c|c|c|}
\hline 7 & $\begin{array}{l}\text { Listen for } \\
\text { main ideas } \\
\text { first and } \\
\text { then } \\
\text { details. }\end{array}$ & $\begin{array}{l}\mathrm{r} \\
\mathrm{p}\end{array}$ & $\begin{array}{l}.011 \\
.908\end{array}$ & $\begin{array}{l}-.001 \\
.993\end{array}$ & $\begin{array}{l}-.040 \\
.673\end{array}$ & $\begin{array}{l}.012 \\
.899\end{array}$ & $\begin{array}{l}.012 \\
.896\end{array}$ & $\begin{array}{l}-.027 \\
.776\end{array}$ & $\begin{array}{l}-.004 \\
.968\end{array}$ & $\begin{array}{l}-.038 \\
.687\end{array}$ \\
\hline 8 & $\begin{array}{l}\text { Choose } \\
\text { different } \\
\text { kinds of } \\
\text { input to } \\
\text { listen. }\end{array}$ & $\begin{array}{l}\mathrm{r} \\
\mathrm{p}\end{array}$ & $\begin{array}{l}.059 \\
.528\end{array}$ & $\begin{array}{l}-.025 \\
.787\end{array}$ & $\begin{array}{l}.176 \\
.060\end{array}$ & $\begin{array}{l}-.018 \\
.845\end{array}$ & $\begin{array}{l}-.001 \\
.995\end{array}$ & $\begin{array}{l}-.044 \\
.641\end{array}$ & $\begin{array}{l}-.025 \\
.789\end{array}$ & $\begin{array}{c}-.064 \\
.500\end{array}$ \\
\hline 9 & $\begin{array}{l}\text { Make } \\
\text { mental or } \\
\text { written } \\
\text { summary } \\
\text { of key } \\
\text { informatio } \\
\text { n }\end{array}$ & $\begin{array}{l}\mathrm{r} \\
\mathrm{p}\end{array}$ & $\begin{array}{l}.066 \\
.482\end{array}$ & $\begin{array}{l}.098 \\
.299\end{array}$ & $\begin{array}{l}.241 * * \\
.009\end{array}$ & $\begin{array}{l}.014 \\
.886\end{array}$ & $\begin{array}{l}.076 \\
.401\end{array}$ & $\begin{array}{l}.053 \\
.575\end{array}$ & $\begin{array}{l}.207 * \\
.026\end{array}$ & $\begin{array}{l}.066 \\
.482\end{array}$ \\
\hline $\begin{array}{l}1 \\
0\end{array}$ & $\begin{array}{l}\text { Apply the } \\
\text { vocabular } \\
\mathrm{y} \text {, phrases } \\
\text { and } \\
\text { grammar }\end{array}$ & $\begin{array}{l}\mathrm{r} \\
\mathrm{p}\end{array}$ & $\begin{array}{l}-.132 \\
.160\end{array}$ & $\begin{array}{l}-.081 \\
.391\end{array}$ & $\begin{array}{l}-.092 \\
.329\end{array}$ & $\begin{array}{l}-.091 \\
.334\end{array}$ & $\begin{array}{l}-.066 \\
.484\end{array}$ & $\begin{array}{c}-.171 \\
.067\end{array}$ & $\begin{array}{l}-.046 \\
.625\end{array}$ & $\begin{array}{c}-.102 \\
.276\end{array}$ \\
\hline $\begin{array}{l}1 \\
1\end{array}$ & $\begin{array}{l}\text { Connect } \\
\text { my prior } \\
\text { knowledg } \\
\text { e to the } \\
\text { existing } \\
\text { informatio } \\
n\end{array}$ & $\begin{array}{l}\mathrm{r} \\
\mathrm{p}\end{array}$ & $\begin{array}{l}-.119 \\
.205\end{array}$ & $\begin{array}{l}.088 \\
.348\end{array}$ & $\begin{array}{l}-.058 \\
.541\end{array}$ & $\begin{array}{l}.004 \\
.965\end{array}$ & $\begin{array}{l}.015 \\
.870\end{array}$ & $\begin{array}{l}.032 \\
.731\end{array}$ & $\begin{array}{l}.004 \\
.967\end{array}$ & $\begin{array}{l}.012 \\
.900\end{array}$ \\
\hline $\begin{array}{l}1 \\
2\end{array}$ & $\begin{array}{l}\text { Do } \\
\text { translation }\end{array}$ & $\begin{array}{l}\mathrm{r} \\
\mathrm{p}\end{array}$ & $\begin{array}{l}.319 * * \\
.001\end{array}$ & $\begin{array}{l}.210 * \\
.024\end{array}$ & $\begin{array}{l}.174 \\
.063 \\
\end{array}$ & $\begin{array}{l}.063 \\
.502\end{array}$ & $\begin{array}{l}.128 \\
.172 \\
\end{array}$ & $\begin{array}{l}.104 \\
.268\end{array}$ & $\begin{array}{l}.181 \\
.052 \\
\end{array}$ & $\begin{array}{l}.188^{*} \\
.044\end{array}$ \\
\hline $\begin{array}{l}1 \\
3\end{array}$ & $\begin{array}{l}\text { Wear } \\
\text { earphones } \\
\text { or } \\
\text { headphon } \\
\text { es }\end{array}$ & $\begin{array}{l}\mathrm{r} \\
\mathrm{p}\end{array}$ & $\begin{array}{l}.121 \\
.199\end{array}$ & $\begin{array}{l}.196 * \\
.036\end{array}$ & $\begin{array}{l}.155 \\
.099\end{array}$ & $\begin{array}{l}.144 \\
.125\end{array}$ & $\begin{array}{l}.180 \\
.055\end{array}$ & $\begin{array}{l}.084 \\
.370\end{array}$ & $\begin{array}{l}.079 \\
.399\end{array}$ & $\begin{array}{l}.142 \\
.130\end{array}$ \\
\hline
\end{tabular}

As seen in Table7, the first group of correlation included the cognitive strategy labeled item 9 and two different listening problems labeled items $\mathrm{h}$ and 1 . Specifically, the first correlation was present between the present strategy and the listening problem marked item $\mathrm{h}(\mathrm{r}=.241, \mathrm{p}=.009)$. The coefficient value of $r=.207$, along with the $p$-value $=.026$ also indicated a positive correlation of the strategy and the problem marked item 1 . Specifically, when students could not understand every single word in the listening text because the speakers pronounced the words unclearly and made lots of reductions, students tried to get the key words in order to make a summary of key information.

Similarly, the second group of correlation presented in Table 7 comprised of between the strategy marked item 12 and listening problems marked items $\mathrm{f}, \mathrm{g}$ and $\mathrm{m}$. The first correlation between the present strategy and listening problem marked item $\mathrm{f}$ was positive and significant $(\mathrm{r}=.391, \mathrm{p}=.001)$. However, the correlation values and significance levels among the rest of variables in this group were not either strong or considerable. In detail, the second correlation existed between the present cognitive strategy and the problem marked item $\mathrm{g}(\mathrm{r}=.210, \mathrm{p}=.024)$. The coefficient value and the $\mathrm{p}-$ value revealed a positive correlation between these two variables, but the correlation was not strong. In a same vein, the correlation of the present strategy with the problem marked item $\mathrm{m}$ was positive but not strong either $(\mathrm{r}=.188, \mathrm{p}=.044)$. In brief, this strategy was judged to be a solution that might sometimes help participants deal with the presently mentioned listening problems.

Finally, participants tended to wear earphones while listening in order to listen more clearly just in case the speakers spoke too fast. This showed a correlation between the cognitive strategy marked item 13 and the problem labeled item g. The coefficient value of $r=.196$ and the p-value of .036 indicated a positive correlation between these two variables. 
Correlations between Listening Comprehension Problems Encountered By English Majors and Their Coping Strategies

\subsubsection{The Correlation between Problems Related to the Speaker and Socio-Affective Strategies}

The calculation of Pearson's correlation coefficient together with subsequent significance testing was done in order to discover if there was any relationship among the variables which belonged to the group of problems related to the speaker and socio affective strategies. The correlation output produced from SPSS was presented in Table 8 as follows.

Table8. Correlation between Problems Related to the Speaker and Socio-Affective Strategies

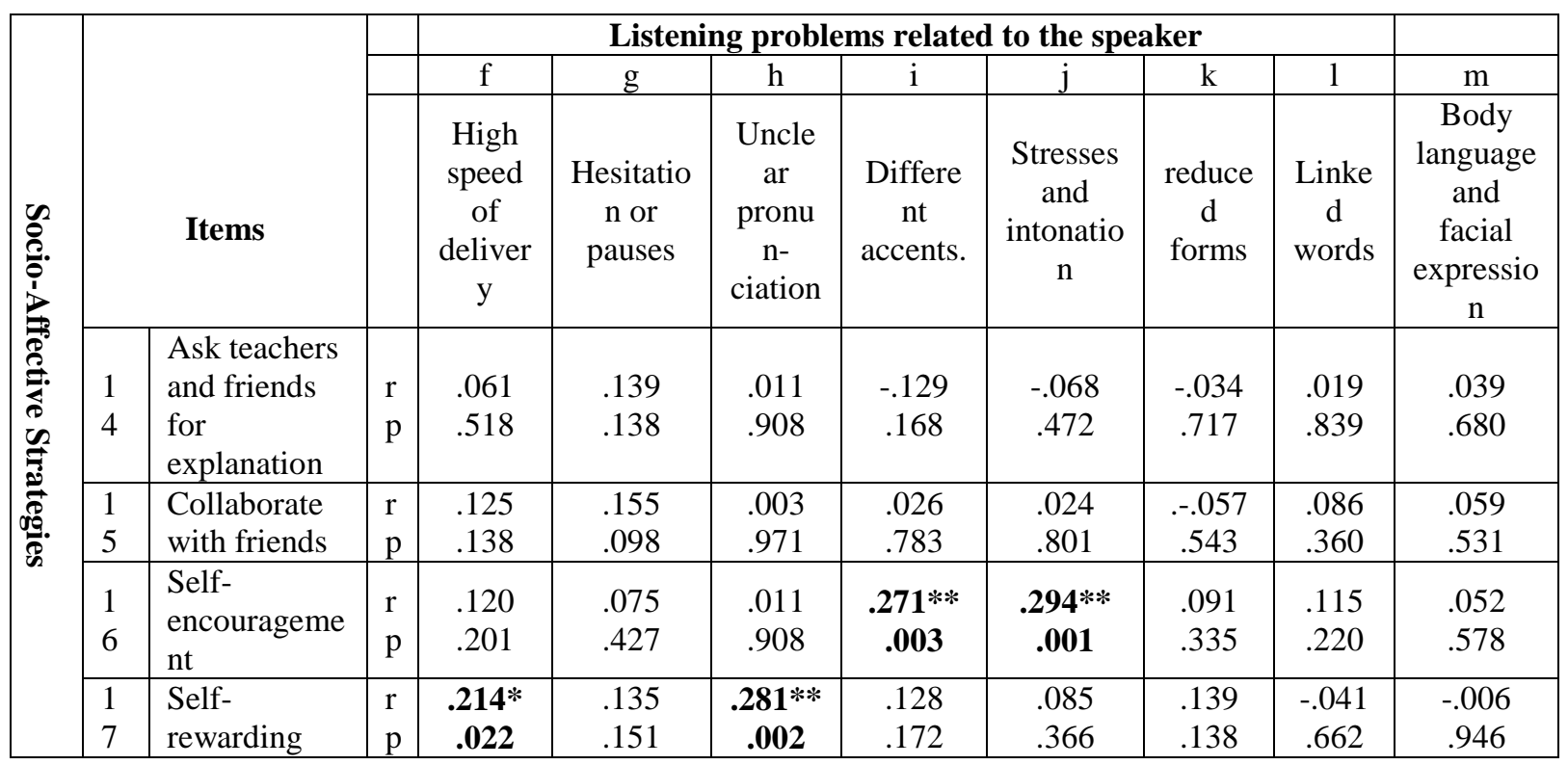

According to Table 8, there were two positive correlations between the socio-affective strategy marked item 16 and the listening problems marked items $i$ and j. Self-motivation to overcome listening difficulties and make progress was considered one of the most useful strategies that the participants employed to deal with language and linguistic barriers in terms of the speakers' accents (item i) and the speakers' stresses and intonation (item j). Specifically, this strategy and the problem of encountering the speakers' different accents were positively correlated $(r=.271, p=.003)$. In addition, the present strategy also had a close correlation with the problems of suffering the speaker's stresses and intonation $(\mathrm{r}=.294, \mathrm{p}=.001)$.

One more group of correlation shown in Table 8 was between the strategy marked item 17 and the two listening problems marked items $\mathrm{f}$ and $\mathrm{h}$. Clearly, the correlation of the present strategy with item $\mathrm{f}$ was positive, but not strong, clarified by the coefficient value of $r=.214$ and the $p$-value of .022. In contrast, the $14^{\text {th }}$ solution and the listening problem labeled item $\mathrm{h}$ were positively and a bit more strongly correlated, demonstrated by $\mathrm{r}=.281$ and $\mathrm{p}=.002$.

In conclusion, socio-affective strategies were not the main solutions in dealing with listening problems related to the speakers compared with metacognitive strategies and cognitive strategies. However, they sometimes helped participants handle some listening difficulties of this type.

\subsubsection{The Correlation between Problems Related to the Listener and Metacognitive Strategies}

The calculation of Pearson's correlation coefficient together with subsequent significance testing was done in order to discover if there was any relationship among the variables which belonged to the group of problems related to the listener and metacognitive strategies. The correlation output produced from SPSS is presented in Table 9 as follows.

Table9. Correlation between Problems Related to the Listener and Metacognitive Strategies

\begin{tabular}{|l|l|l|l|l|l|l|l|}
\hline \multirow{2}{*}{} & & \multicolumn{6}{|l|}{ Listening problems related to the listener } \\
\cline { 3 - 8 } & & $\mathrm{n}$ & $\mathrm{o}$ & $\mathrm{p}$ & $\mathrm{q}$ & $\mathrm{r}$ \\
\cline { 3 - 8 } & & $\begin{array}{l}\text { Slow to recall } \\
\text { in linterested } \\
\text { the meaning of } \\
\text { unfamiliar- } \\
\text { sounded words }\end{array}$ & $\begin{array}{l}\text { Limited } \\
\text { contextual } \\
\text { knowledge }\end{array}$ & $\begin{array}{l}\text { Limited } \\
\text { language } \\
\text { knowledge }\end{array}$ & $\begin{array}{l}\text { Anxiety } \\
\text { about } \\
\text { listening }\end{array}$ \\
\hline
\end{tabular}


Correlations between Listening Comprehension Problems Encountered By English Majors and Their Coping Strategies

\begin{tabular}{|c|c|c|c|c|c|c|c|}
\hline 1 & & $\mathrm{p}$ & .931 & .907 & .363 & .835 & .469 \\
\hline 2 & $\begin{array}{ll}\text { Suitable listening } \\
\text { text }\end{array}$ & $\begin{array}{l}\mathrm{r} \\
\mathrm{p}\end{array}$ & $\begin{array}{l}.033 \\
.727 \\
\end{array}$ & $\begin{array}{l}.076 \\
.422 \\
\end{array}$ & $\begin{array}{l}.283^{* * *} \\
.002\end{array}$ & $\begin{array}{l}.213 * \\
.023 \\
\end{array}$ & $\begin{array}{l}.178 \\
.057 \\
\end{array}$ \\
\hline 3 & $\begin{array}{l}\text { Read the audio } \\
\text { scripts for } \\
\text { unfamiliar words }\end{array}$ & $\begin{array}{l}\mathrm{r} \\
\mathrm{p}\end{array}$ & $\begin{array}{l}-.156 \\
.097\end{array}$ & $\begin{array}{l}-.005 \\
.958\end{array}$ & $\begin{array}{l}.297 * * \\
.001\end{array}$ & $\begin{array}{l}.173 \\
.064\end{array}$ & $\begin{array}{l}.123 \\
.191\end{array}$ \\
\hline 4 & $\begin{array}{l}\text { Listen to different } \\
\text { accents }\end{array}$ & $\begin{array}{l}\mathrm{r} \\
\mathrm{p}\end{array}$ & $\begin{array}{l}-.146 \\
.119\end{array}$ & $\begin{array}{l}-.098 \\
.296\end{array}$ & $\begin{array}{l}-.025 \\
.788\end{array}$ & $\begin{array}{l}-.009 \\
.922\end{array}$ & $\begin{array}{l}-.085 \\
.364\end{array}$ \\
\hline 5 & $\begin{array}{l}\text { Review the } \\
\text { listening materials }\end{array}$ & $\begin{array}{l}\mathrm{r} \\
\mathrm{p}\end{array}$ & $\begin{array}{l}-.012 \\
.898\end{array}$ & $\begin{array}{l}.112 \\
.232 \\
\end{array}$ & $\begin{array}{l}.237 * \\
.011\end{array}$ & $\begin{array}{l}.197 * \\
.035\end{array}$ & $\begin{array}{l}.222 * \\
.017\end{array}$ \\
\hline 6 & $\begin{array}{l}\text { Evaluate what has } \\
\text { been done }\end{array}$ & $\begin{array}{l}\mathrm{r} \\
\mathrm{p}\end{array}$ & $\begin{array}{l}-.066 \\
.484\end{array}$ & $\begin{array}{l}-.123 \\
.191\end{array}$ & $\begin{array}{l}.125 \\
.183\end{array}$ & $\begin{array}{l}.069 \\
.464\end{array}$ & $\begin{array}{l}-.027 \\
.775\end{array}$ \\
\hline
\end{tabular}

Table 9 shows that there were two positive correlations of the metacognitive strategy marked item 2 with two listening problems marked items $\mathrm{p}$ and $\mathrm{q}$. The first relationship was present between the present solution and the listening problem (item $\mathrm{p}, \mathrm{r}=.281, \mathrm{p}=.002$ ). The coefficient value and the $\mathrm{p}$ value revealed a positive and fairly strong correlation between these two variables. In other words, as students' contextual knowledge was limited, they solved this problem by choosing listening materials not beyond their ability. In addition, another correlation was also found between the present strategy and the listening difficulty marked item $\mathrm{q}(\mathrm{r}=.213, \mathrm{p}=.023)$. The values of $\mathrm{r}$ and $\mathrm{p}$ showed a positive and insignificant correlation between the two variables. Since the participants' language knowledge was not profound, they chose the suitable listening texts to listen.

One more remarkable correlation presented in Table 9 was between the $3^{\text {rd }}$ strategy and the listening difficulty marked item $\mathrm{p}$. This strong and positive correlation was demonstrated by the coefficient value of $r=.297$ and the $p$-value of .001 . This means that when participants did not comprehend the content of the listening text because of a lack of contextual knowledge, they read the audio scripts to catch on to the content and broaden their knowledge as well.

The last group of correlation showed in Table 9 existed between the $5^{\text {th }}$ strategy and the listening difficulties marked items $\mathrm{p}, \mathrm{q}$ and $\mathrm{r}$. Although all the correlations were positive, they were not strong. Specifically, the relationship between the $5^{\text {th }}$ strategy and the listening problem labeled item $\mathrm{p}$ were positive but not much significant, clarified by the coefficient value of $r=.237$ and the p-value of .011 . Similarly, the $5^{\text {th }}$ solution and the listening difficulty marked item $\mathrm{q}$ were positively, but not significantly correlated $(r=.197, p=.035)$. In a same vein, the coefficient value of $r=.222$, together with the p-value of .017 indicated a positive correlation between the two variables (the $5^{\text {th }}$ strategy and listening problem marked item $r$ ). In conclusion, the strategy of reviewing the listening materials in a planned way after class had the positive correlations towards the three listening difficulties. Even though the significance levels were not very high, participants could employ this solution to handle listening problems in terms of lack of contextual and language knowledge, and relieving anxiety.

\subsubsection{The Correlation between Problems Related to the Listener and Cognitive Strategies}

The calculation of Pearson's correlation coefficient together with subsequent significance testing was done in order to discover if there was any relationship among the variables which belonged to the group of problems related to the listener and cognitive strategies. The correlation output produced from SPSS was presented in Table 10 as follows:

Table10. Correlation between Problems Related to the Listener and Cognitive Strategies

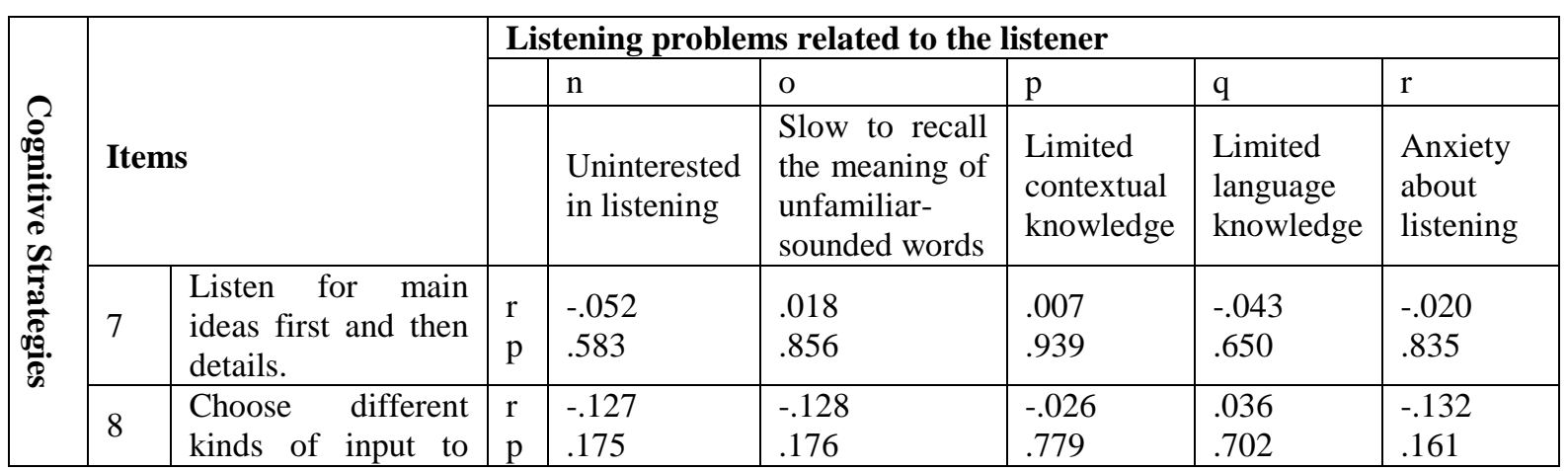


Correlations between Listening Comprehension Problems Encountered By English Majors and Their Coping Strategies

\begin{tabular}{|c|c|c|c|c|c|c|c|}
\hline & listen & & & & & & \\
\hline 9 & $\begin{array}{l}\text { Make mental or } \\
\text { written summary of } \\
\text { key information }\end{array}$ & $\begin{array}{l}\mathrm{r} \\
\mathrm{p}\end{array}$ & $\begin{array}{l}.024 \\
.798\end{array}$ & $\begin{array}{l}.064 \\
.499\end{array}$ & $\begin{array}{l}.058 \\
.537\end{array}$ & $\begin{array}{l}-.028 \\
.770\end{array}$ & $\begin{array}{l}.156 \\
.096\end{array}$ \\
\hline 10 & $\begin{array}{l}\text { Apply the } \\
\text { vocabulary, phrases } \\
\text { and grammar }\end{array}$ & $\begin{array}{l}\mathrm{r} \\
\mathrm{p}\end{array}$ & $\begin{array}{l}-.217 * \\
.020\end{array}$ & $\begin{array}{l}-.013 \\
.891\end{array}$ & $\begin{array}{l}.000 \\
.999\end{array}$ & $\begin{array}{l}.051 \\
.590\end{array}$ & $\begin{array}{l}-.128 \\
.173\end{array}$ \\
\hline 11 & $\begin{array}{l}\text { Connect my prior } \\
\text { knowledge to the } \\
\text { existing information }\end{array}$ & $\begin{array}{l}\mathrm{r} \\
\mathrm{p}\end{array}$ & $\begin{array}{l}-.101 \\
.282\end{array}$ & $\begin{array}{l}.113 \\
.231\end{array}$ & $\begin{array}{l}-.036 \\
.703\end{array}$ & $\begin{array}{l}.071 \\
.451\end{array}$ & $\begin{array}{l}-.023 \\
.807\end{array}$ \\
\hline 12 & Do translation & $\begin{array}{l}\mathrm{r} \\
\mathrm{p}\end{array}$ & $\begin{array}{l}.133 \\
.156\end{array}$ & $\begin{array}{l}.251 * * \\
007\end{array}$ & $\begin{array}{l}.316^{* * *} \\
.001\end{array}$ & $\begin{array}{l}.288 * * \\
.002\end{array}$ & $\begin{array}{l}.221 * \\
.018\end{array}$ \\
\hline 13 & $\begin{array}{l}\text { Wear earphones or } \\
\text { headphones }\end{array}$ & $\begin{array}{l}\mathrm{r} \\
\mathrm{p}\end{array}$ & $\begin{array}{l}.004 \\
.969\end{array}$ & $\begin{array}{l}.073 \\
.439\end{array}$ & $\begin{array}{l}.120 \\
.203\end{array}$ & $\begin{array}{l}-.025 \\
.794\end{array}$ & $\begin{array}{l}.083 \\
.376\end{array}$ \\
\hline
\end{tabular}

As showed in Table 10, one group of correlation was present between the $12^{\text {th }}$ listening strategy and the listening difficulties marked items o, p, q and r. In particular, when participants were slow to recall the meanings of words that sounded familiar (item o), they tended to translate the content into Vietnamese. The positive and significant correlation between these two variables were demonstrated by the coefficient value of $r=.251$ and the $p$-value of .007 . Next, the $16^{\text {th }}$ solution was also utilized to deal with the difficulty in lacking the contextual knowledge (item $\mathrm{p}$ ). These two variables were positively and significantly correlated $(\mathrm{r}=.316, \mathrm{p}=.001)$. In addition, similar to the listening problem marked item $\mathrm{p}$, the difficulty marked item $\mathrm{q}$ might be solved by using the present strategy. The value of $\mathrm{r}=.288$ and the $\mathrm{p}$-value of .002 exposed a positive and remarkable correlation between these two variables. Finally, another correlation was found between the present solution and the listening problem marked item $r$. The correlation was positive; it was, however, not significant in comparison with the above-mentioned correlations. This premise was proved by the coefficient value of $r=.221$ and the p-value of .018. In summary, some cognitive strategies may be applied to solve the listening problems by the participants. Moreover, those strategies had positive and significant correlations with the listening difficulties handled by them.

\subsubsection{The Correlation between Problems Related to the Listener and Socio-Affective Strategies}

The calculation of Pearson's correlation coefficient together with subsequent significance testing was done in order to discover if there was any relationship among the variables which belonged to the group of problems related to the listener and socio-affective strategies. The correlation output produced from SPSS was presented in Table 11 as follows.

Table11. Correlation between Problems Related to the Listener and Socio-Affective Strategies

\begin{tabular}{|c|c|c|c|c|c|c|c|c|}
\hline \multirow{7}{*}{ 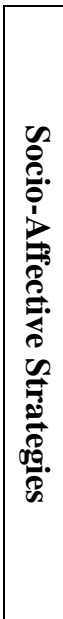 } & & & \multicolumn{6}{|c|}{ Listening problems related to the listener } \\
\hline & & & & $\mathrm{n}$ & o & $\mathrm{p}$ & $\mathrm{q}$ & $\mathrm{r}$ \\
\hline & \multicolumn{2}{|c|}{ Items } & & Uninterested & $\begin{array}{l}\text { Slow to recall } \\
\text { the meaning of }\end{array}$ & Limited & Limited & Anxiety \\
\hline & 14 & $\begin{array}{ll}\text { Ask teachers and } \\
\text { friends } & \text { for } \\
\text { explanation } & \\
\end{array}$ & $\begin{array}{l}\mathrm{r} \\
\mathrm{p}\end{array}$ & $\begin{array}{l}.058 \\
.535\end{array}$ & $\begin{array}{l}.087 \\
.356\end{array}$ & $\begin{array}{l}.164 \\
.081\end{array}$ & $\begin{array}{l}.191 * \\
.041\end{array}$ & $\begin{array}{l}.021 \\
.823\end{array}$ \\
\hline & 15 & $\begin{array}{l}\text { Collaborate with } \\
\text { friends }\end{array}$ & $\begin{array}{l}\mathrm{r} \\
\mathrm{p}\end{array}$ & $\begin{array}{l}-.099 \\
.294\end{array}$ & $\begin{array}{l}.082 \\
.386\end{array}$ & $\begin{array}{l}.259 * * \\
.005\end{array}$ & $\begin{array}{l}.204 * \\
.028\end{array}$ & $\begin{array}{l}-.018 \\
.846\end{array}$ \\
\hline & 16 & $\begin{array}{l}\text { Self- } \\
\text { encouragement }\end{array}$ & $\begin{array}{l}\mathrm{r} \\
\mathrm{p}\end{array}$ & $\begin{array}{l}.201 * \\
.024\end{array}$ & $\begin{array}{l}.262 * * \\
.005\end{array}$ & $\begin{array}{l}.307 * * \\
.001\end{array}$ & $\begin{array}{l}.348 * * \\
.000\end{array}$ & $\begin{array}{l}.199 * \\
.033\end{array}$ \\
\hline & 17 & Self-rewarding & $\begin{array}{l}\mathrm{r} \\
\mathrm{p}\end{array}$ & $\begin{array}{l}.191 * \\
.040\end{array}$ & $\begin{array}{l}-.054 \\
.565\end{array}$ & $\begin{array}{l}-.012 \\
.897\end{array}$ & $\begin{array}{l}.014 \\
.882\end{array}$ & $\begin{array}{l}.199 * \\
.033\end{array}$ \\
\hline
\end{tabular}

As showed in Table 11, socio-affective strategies were regarded as effective solutions to the listening problems related to the listener as follows.

The first correlation was present between the $14^{\text {th }}$ strategy and the listening problem marked item $\mathrm{q}$. Although the correlation was positive, it was not significant according to the p-value of .041. In 
particular, because participants' contextual knowledge was not profound, they tended to ask teachers or peers for explanation or verification.

The second group of correlations was between the $15^{\text {th }}$ strategy and two different listening problems marked items $\mathrm{p}$ and $\mathrm{q}$. The first relationship in this group was formed between the present strategy and the listening difficulty marked item $p$. It is clear in Table 9 that these two variables were positively and significantly correlated $(r=.259, \mathrm{p}=.005)$. Next, the coefficient value of $r=.204$ and the p-value of .028 revealed another positive correlation of the $15^{\text {th }}$ strategy with the listening problem marked item q. In brief, on account of being limited in contextual and language knowledge, participants collaborated with friends to learn and check the tasks for accuracy.

The third group of correlations consisted of between the $16^{\text {th }}$ strategy and all listening problems related to the listener. Self-motivation was considered one of the best strategies to deal with listening problems perceived by the participants. Specifically, the first correlation in this group was present between the present strategy and the listening problem marked item $\mathrm{n}$. The participants had listening problem as they had no interest in listening, and in order to solve the problems, they encouraged themselves to make progress. This correlation was clarified by the coefficient value of $r=.201$ and the p-value of .024. In addition, self-motivation strategy also had a considerable influence on those who were slow to recall the meaning of the familiar-sounded words (item $o$ ). This was proved by the values of $r=.262$, and $p=.005$. Moreover, participants also encouraged themselves to make progress due to their lack of contextual and language knowledge (items $p$ and $q$ ). The correlation of the present strategy and the listening difficulty marked item $\mathrm{p}$ was positive and significant, demonstrated by $\mathrm{r}=$ .307 and $\mathrm{p}=.001$. Following that, the $16^{\text {th }}$ solution and the problem marked item q were positively and significantly correlated with the value of $r=.384$ and the $p$-value $=.000$ which stood the highest in ranking in terms of the significance level in comparison with the others'. Last but not least, the final correlation in this group was discovered between the present strategy and the listening problem marked item $r$. In detail, self-encouragement helped participants relieve anxiety about listening, clarified by $\mathrm{r}=.199$ and $\mathrm{p}=.033$.

The relationship between the $17^{\text {th }}$ strategy and the two different listening difficulties marked items $\mathrm{n}$ and $r$ showed other two correlations. In particular, the strategy of self-rewarding helped create the participants' interest in listening (item $n$ ). The correlation between these two variables was positive, but not highly significant, clarified by the value of $r=.191$, and the $\mathrm{p}$-value $=.040$. Similarly, although the present strategy and the listening problem marked item $r$ were positively correlation, the significance level was not considerable $(\mathrm{r}=.1991, \mathrm{p}=.033)$. In brief, the participants found this socio-affective strategy useful for getting around the listening problems related to listening interest and listening anxiety.

\subsubsection{The Correlation between Problems Related to the Physical Setting and Metacognitive Strategies}

The calculation of Pearson's correlation coefficient together with subsequent significance testing was done in order to discover if there was any relationship among the variables which belonged to the group of problems related to the physical setting and metacognitive strategies. The correlation output produced from SPSS was presented in Table 12 as follows.

Table12. Correlation between Problems Related to the Physical Setting and Metacognitive Strategies

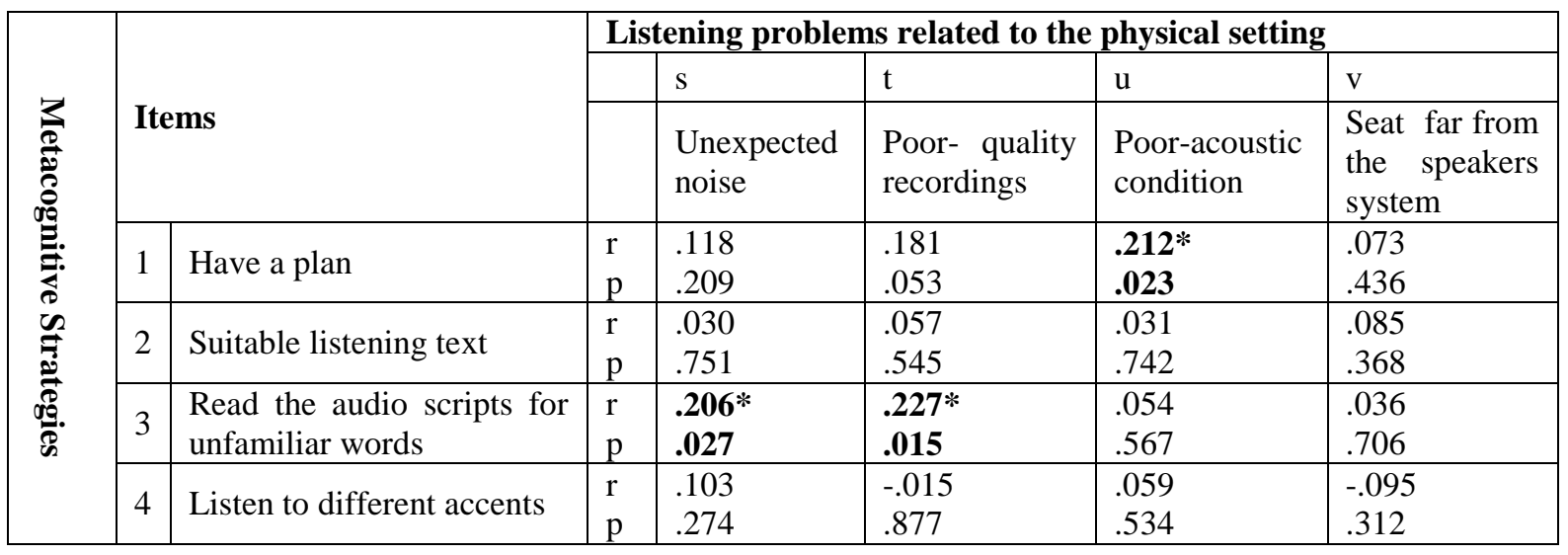


Correlations between Listening Comprehension Problems Encountered By English Majors and Their Coping Strategies

\begin{tabular}{|l|l|l|l|l|l|l|l|l|}
\hline & \multirow{2}{*}{5} & $\begin{array}{l}\text { Review the listening } \\
\text { materials }\end{array}$ & $\mathrm{r}$ & $\mathbf{. 2 0 3 *}$ & -.005 & .127 &. $\mathbf{2 2 7} *$ \\
& \multirow{2}{*}{6} & $\begin{array}{l}\text { Evaluate what has been } \\
\text { done }\end{array}$ & $\mathrm{r}$ & .064 & .030 & .958 & .178 & .015 \\
\hline & & $\mathrm{p}$ & .494 & .570 & .106 & .050 \\
\hline
\end{tabular}

According to Table 12, the first correlation was present between the strategy marked item 1 and the listening strategy marked item $\mathrm{u}$. The correlation between these two variables were positive, proved by the coefficient value of $r=.212$ and the $p$-value of .023 . Apparently, to avoid suffering from poor acoustic conditions in the classroom, the participant came up with a listening plan.

The second group of correlation was discovered between the $3^{\text {rd }}$ strategy and the two different listening difficulties marked items s and t. Specifically, reading the audio scripts and consulting dictionaries for meaning and pronunciation was employed by the participants when they had listening problems related to the unexpected noise outside (item $\mathrm{s}$ ) and poor-quality recordings (item $\mathrm{t}$ ). Numerically, the positive correlation of the present strategy with the listening problem marked item $\mathrm{s}$ was depicted through the values of $r=.206$ and $p=.027$. Following that, the values of $r=.227$ and $p$ $=.015$ referred to the correlation of the present solution with the listening problem marked item $\mathrm{t}$.

The metacognitive strategy marked item 5, which was about reviewing the listening materials in a planned way after class, was considered a good solution to listening problems caused by unexpected noise outside (item s) and the far distance from the participants' seats to the speakers system (item v). As showed in Table 12, the coefficient value of $r=.203$ exposed a positive correlation between the present strategy and the listening trouble marked item s. However, the significance level was not high, demonstrated by the p-value of .030. The final correlation was established between the present solution and the listening difficulty marked item $\mathrm{v}$. These two variables were positively and pretty significantly correlated $(\mathrm{r}=.227, \mathrm{p}=.015)$.

\subsubsection{The Correlation between Problems Related to the Physical Setting and Cognitive Strategies}

The calculation of Pearson's correlation coefficient together with subsequent significance testing was done in order to discover if there was any relationship among the variables which belonged to the group of problems related to the physical setting and cognitive strategies. The correlation output produced from SPSS was presented in Table 13 as follows.

Table13. Correlation between Problems Related to the Physical Setting and Cognitive Strategies

\begin{tabular}{|c|c|c|c|c|c|c|c|}
\hline & & & & g problems & lated to the pl & sical setti & \\
\hline & & & & $\mathrm{s}$ & $\mathrm{t}$ & $\mathrm{u}$ & $\mathrm{V}$ \\
\hline & Ite & & & & & Poor- & $\begin{array}{ll}\text { Seat } & \text { far } \\
\text { from } & \text { the }\end{array}$ \\
\hline & 7 & $\begin{array}{l}\text { Listen for main ideas first } \\
\text { and then details }\end{array}$ & $\begin{array}{l}\mathrm{r} \\
\mathrm{p}\end{array}$ & $\begin{array}{l}-.025 \\
.795 \\
\end{array}$ & $\begin{array}{l}.181 \\
.052 \\
\end{array}$ & $\begin{array}{l}.081 \\
.389\end{array}$ & $\begin{array}{l}.039 \\
.679\end{array}$ \\
\hline 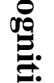 & 8 & $\begin{array}{l}\text { Choose different kinds of } \\
\text { input to listen }\end{array}$ & $\begin{array}{l}\mathrm{r} \\
\mathrm{p}\end{array}$ & $\begin{array}{l}.273 * \\
.011\end{array}$ & $\begin{array}{l}.219 * \\
.018\end{array}$ & $\begin{array}{l}.192 * \\
.040\end{array}$ & $\begin{array}{l}.028 \\
.769\end{array}$ \\
\hline 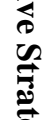 & 9 & $\begin{array}{llr}\text { Make mental or } & \text { written } \\
\text { summary } & \text { of } & \text { key } \\
\text { information } & & \end{array}$ & $\begin{array}{l}\mathrm{r} \\
\mathrm{p}\end{array}$ & $\begin{array}{l}.164 \\
.080\end{array}$ & $\begin{array}{l}.214^{*} \\
.021\end{array}$ & $\begin{array}{l}.158 \\
.092\end{array}$ & $\begin{array}{l}.134 \\
.154\end{array}$ \\
\hline$\frac{0}{8.9}$ & 10 & $\begin{array}{l}\text { Apply the vocabulary, } \\
\text { phrases and grammar }\end{array}$ & $\begin{array}{l}\mathrm{r} \\
\mathrm{p}\end{array}$ & $\begin{array}{l}.153 \\
.102 \\
\end{array}$ & $\begin{array}{l}.068 \\
.470 \\
\end{array}$ & $\begin{array}{l}.004 \\
.964\end{array}$ & $\begin{array}{l}-.030 \\
.754 \\
\end{array}$ \\
\hline & 11 & $\begin{array}{l}\text { Connect my prior } \\
\text { knowledge to the existing } \\
\text { information }\end{array}$ & $\begin{array}{l}\mathrm{r} \\
\mathrm{p}\end{array}$ & $\begin{array}{l}.125 \\
.183\end{array}$ & $\begin{array}{l}.00 \\
.930\end{array}$ & $\begin{array}{l}.021 \\
.820\end{array}$ & $\begin{array}{l}.080 \\
.397\end{array}$ \\
\hline & 12 & Do translation & $\begin{array}{l}\mathrm{r} \\
\mathrm{p}\end{array}$ & $\begin{array}{l}.123 \\
.192\end{array}$ & $\begin{array}{l}.121 \\
.197\end{array}$ & $\begin{array}{l}.045 \\
.636\end{array}$ & $\begin{array}{l}-.031 \\
.742\end{array}$ \\
\hline & 13 & $\begin{array}{l}\text { Wear earphones or } \\
\text { headphones }\end{array}$ & $\begin{array}{l}\mathrm{r} \\
\mathrm{p}\end{array}$ & $\begin{array}{l}.246^{* * *} \\
.008\end{array}$ & $\begin{array}{l}.080 \\
.394 \\
\end{array}$ & $\begin{array}{l}.025 \\
.787\end{array}$ & $\begin{array}{l}-.126 \\
.179 \\
\end{array}$ \\
\hline
\end{tabular}

According to Table 13, the first group of correlation was between the $8^{\text {th }}$ listening learning strategy and the three different listening troubles labeled items $\mathrm{s}$, $\mathrm{t}$, and $\mathrm{u}$. Firstly, there was a positive correlation existing between the present solution with the listening problem marked item s, illustrated by the values of $r=.271$ and $p=.011$. Besides, the next correlation was seen between the strategy and 
the listening trouble marked item t. Similar to the first correlation in this group, these two variables were positively correlated $(\mathrm{r}=.219, \mathrm{p}=0.18)$. The final relationship was formed between this strategy and the listening problem marked item $u$. These two variables showed the least positive and significant correlation compared to the other two ones based on the coefficient values $(\mathrm{r}=.192, \mathrm{p}=$ 0.40). However, the correlations of the present strategy with the listening difficulties were not significant; i.e. this strategy was "sometimes" either useful or useless for students to sidestep listening problems.

The next correlation group was found between the cognitive strategy marked item 9 and the listening problem marked item t. Although these two variables were positively correlated $(r=.214)$, the significance level was not high $(\mathrm{p}=.021)$.

The last correlation group between the $13^{\text {th }}$ strategy and the listening difficulty marked item $\mathrm{s}$ achieved a dominant position based on the coefficient values of $r=.246$, and $p=.008$. In other words, to avoid listening problem resulted from unexpected noise outside, participants wore earphones and headphones while listening.

\subsubsection{The Correlation between Problems Related to the Physical Setting and Socio-Affective Strategies}

The calculation of Pearson's correlation coefficient together with subsequent significance testing was done in order to discover if there was any relationship among the variables which belonged to the group of problems related to the physical setting and socio-affective strategies. The correlation output produced from SPSS was presented in Table 14 as follows.

Table14. Correlation between Problems Related to the Physical Setting and Socio-Affective Strategies

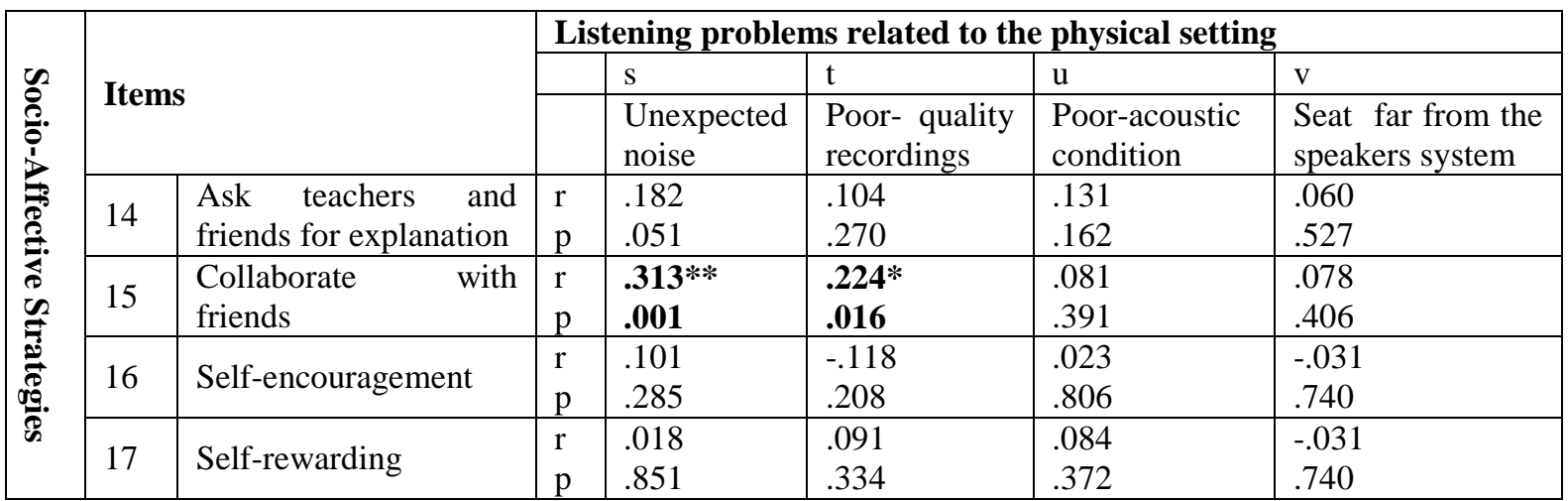

Table 14 highlights a group of correlation between the socio-affective strategy marked item 15 and the listening problems marked items $\mathrm{s}$ and $\mathrm{t}$. The first dominant correlation was found between the present solution and the listening problem marked item $\mathrm{s}$. The two variables were positively and significantly correlated $(\mathrm{r}=.313, \mathrm{p}=.001)$. Following that, the coefficient values of $\mathrm{r}=.224$ and $\mathrm{p}=$ .016 demonstrated another correlation of the strategy with the listening problem marked item $\mathrm{t}$. In brief, participants collaborated with friends to learn and check listening performances when there were some listening problems related to the outside unexpected noise and poor-quality recordings.

\subsection{Discussion}

\subsubsection{Metacognitive Strategies and Listening Comprehension Problems}

The findings of the current study demonstrated that metacognitive strategies and listening comprehension problems were positively and significantly correlated. Specifically, employing metacognitive strategies helped students choose the suitable listening texts by which they no longer came across unfamiliar words or complex sentence structures. In addition, this strategy could handle the difficulties including high speed of delivery, different accents, stresses, intonation, and connected speech. Furthermore, those whose contextual and language knowledge was not profound were able to make progress gradually by using this strategy. It is encouraging to compare this figure with that found by Yildiz and Albay (2015) who found that the chosen topics must be interesting enough to motivate the students to produce good performance on the listening task. Next, speed of delivery had to be slower than the normal speech. In addition, native accents should be chosen because the accents of the speakers had strong influences on the understanding of the text. 
Students could comprehend clearly the context of the listening text and broaden their linguistic knowledge, get around the problems of high speed of delivery, different accents and connected speech when they frequently used the strategy of reading the audio scripts. In some cases, problems arisen because of the physical setting factors such as noise or poor-quality recording could be sidestepped with this strategy. This finding corroborates the ideas of Simasangyaporn (2016), who suggested that reading audio scripts fostered better listening comprehension.

In addition, reviewing the learned materials was one of the indispensable metacognitive strategies that some students employed. This practice could help them go over the new words and complex structures that they had learned at school. Besides, implementing this strategy helped learners comprehend more clearly the content which they might fail to gain due to the speaker's high speed of delivery, accents, stresses, intonation, hesitation and pauses while listening at school. More significantly, students' contextual and language knowledge was sure to be advanced when they reviewed the listening materials in a planned way after class. Last but not least, some physical setting factors causing problems such as noise or poor-acoustic condition in the classroom were no longer the big barriers when students had plans to review the lessons after school. This result also agrees with the finding of Bao (2017) who stated that listening to the texts again and again helped remind listeners of the language knowledge and different accents.

The results relating to correlation of metacognitive strategies with listening comprehension problems agree with the findings of other studies in which the role of metacognitive awareness in students' learning outcomes and achievement in different school subjects has been focused. The findings showed an extensive evidence that students' learning outcomes and learning process could be directly affected by their metacognition (Boekaerts, Pintrich, \& Zeidner, 2000; Eilam \& Aharon, 2003; Mokhtari \& Reichard, 2002; Palmer \& Goetz, 1988; Victori \& Lockhart, 1995; Zimmerman \& Schunk, 2001).

\subsubsection{Cognitive Strategies and Listening Comprehension Problems}

According to Derry and Murphy (1986) the cognitive strategy is a problem-solving method employed by the leaners in order to gain the knowledge and skills. Besides, leaners can adopt this strategy to help them process, retain and digest the new information (Goh, 1998). In addition, the findings from previous studies (Goh, 2000; Yildiz \& Albay, 2015; Bao, 2017) showed that the students preferably employed cognitive strategies to deal with listening problems, i.e. this group of strategies played a crucial role in the students' process of listening learning.

The results of the present study disclosed some positive and significant correlations between cognitive strategies and listening difficulties. In other words, some cognitive strategies positively and significantly helped listeners to overcome listening problems. First and foremost, by listening to different kinds of input, students could widen their contextual knowledge and language knowledge as well. In addition, translation strategy facilitated students to understand clearly the content of the listening text, because when they translated the content, they could catch on to the meaning of unknown words and complex structures. More importantly, this helped them broaden their socio and language knowledge. The finding in the study of Goh (2002) showed that an effective listener employed both cognitive and metacognitive strategies to achieve a complete understanding of the listening text, and had the ability to us prior knowledge, linguistic cues and contextual information. However, an unskilled listener was often distracted by unfamiliar words and used only low-level comprehension strategies.

\subsubsection{Socio-Affective Strategies and Listening Comprehension Problems}

Socio-affective strategies performed a significant role in helping listeners improve listening skills. The finding of the present study indicated that the participants asked their teachers and friends to verify and explain their work or the knowledge that they had not acquired before so that they could recognize their strengths and weaknesses. In addition, students found cooperating with friends to learn and check the tasks helpful because they could learn from one another. More significantly, the final strategy was self-motivation. The participants in the present study claimed this strategy to be the key solution supporting them to get more proficient in listening. In accordance with the present results, a previous study has demonstrated that socio-affective strategies could easily reduce apprehension and 
better listening (Aneiro, 1989). In addition, Gilakjani and Sabouri (2016) suggested that feedback or clarification should be given and motivation should be provided on the spot in order to encourage students to perform better.

\section{CONCLuSion}

\subsection{Summary of the Research Findings}

To sum up, the top six most common difficulties perceived by the students were about vocabulary, complex sentence structures, high speed of delivery, unclear pronunciation, different accents, and background knowledge. Following that, the top six most common solutions were listening for main ideas first and then details, listening to different kinds of input, connecting prior knowledge to the existing information of the text, applying the learned vocabulary and grammar to comprehend the content, choosing the suitable listening texts, and reading the audio scripts for new words and for a better understanding of the content. Importantly, the findings in the present study revealed several positive and significant correlations between the listening strategies and factors causing listening problems. In other words, students used these strategies to solve the difficulties that they have encountered.

\subsection{Pedagogical Implications}

\subsubsection{Implications for Students}

Students should employ cognitive strategies in combination with metacognitive and socio-affective strategies in order to boost the effectiveness in listening. Thus, they should be fostered to be selfequipped with vocabulary indifferent fields of knowledge through listening practices using different kinds of input. Furthermore, students are expected to have a plan on what and how to listen, assess their progress and review the listening texts in a planned way. Another suggestion is that students should read the audio scripts of the listening texts to gain a deeper understanding of the contents.

\subsubsection{Implications for Teachers}

In respect of teachers, it is recommended that different types of listening tasks should be provided in order to advance students' background and linguistic knowledge with the support of teachers in terms of explanation or verification for the linguistic features. Besides, teachers should learn about the students' learning styles so as to choose the suitable listening materials to increase their interests. What is more, feedback on students' listening performance is necessary since it could encourage their error correction and strengthen their motivation. More worthily, positive feedback should be given rather than negative comments with the aim of offering incentives to students to make better progress. Last but not least, it is important that teachers should help students to understand clearly what they are expected to do with metacognitive strategies, cognitive strategies and socio-affective strategies. After fully comprehending the listening strategies, students are able to practice listening autonomously and effectively.

\subsection{Recommendations for Further Research}

This research has thrown up many questions in need of further investigation. For example, a further study with more focus on correlations between listening comprehension problems and listening learning strategies is therefore suggested. It would be interesting to conduct a study in which an experimental group and a controlled group should be designed in order to test the effectiveness of the strategies in helping students to cope with the listening difficulties.

\section{REFERENCES}

[1] Ackroyd, S., \& Hughes, J. A. (1981). Data collection in context. Longman.

[2] Aneiro, S. (1989). The influence of receiver apprehension in foreign language learners on listening comprehension among Puerto Rican college students. New You University: New York.

[3] Babbie, E. (1989). Research methods for social work. California: Wadsworth.

[4] Bao, X. (2017). A study on listening strategies instructed by teachers and strategies used by students. International Journal of English Linguistics, 7(2), 186-195.

[5] Bell, J. (2003). Doing your research project: a guide for first-time researchers in education and social science. England: Open University Press. 
Correlations between Listening Comprehension Problems Encountered By English Majors and Their Coping Strategies

[6] Boekaerts, M., Pintrich, P., \& Zeidner, M. (2000). Handbook of self-regulation. San Diego: Academic Press.

[7] Bogdan, R. C., \& Biklen, S. K. (1992). Qualitative research for education: an introduction to theory and methods. Boston: Allyn and Bacon.

[8] Bryman, A. (2001). Social research methods. New York: Oxford University Press.

[9] Chamot, A. U. (2005). Language learning strategy instruction: current issues and research. Annual Review of Applied Linguistics, 25, 112-130.

[10] Cross, J. (2009). Effects of listening strategy instruction on new videotext comprehension. Language Teaching Research, 13(2), 151-176.

[11] Derry, S. J., \& Murphy, D. A. (1986). Designing systems that train learning ability: from theory to practice. Review of Educational Research, 56, 1-39.

[12] Eilam, B., \& Aharon, I. (2003). Students' planning in the process of self-regulated learning. Contemporary Educational Psychology, 28, 304- 334.

[13] Fink, A. (1995). How to sample in surveys. London: SAGE Publications.

[14] George, D., \& Mallery, P. (2003). SPSS for Windows step by step: A simple guide and reference. Boston, MA: Allyn \& Bacon.

[15] Gilakjani, A. P., \& Sabouri, N. B. (2016). Learner's listening comprehension difficulties in English language learning: A literature review. Canadian Center of Science and Education, 9(6), 123-133.

[16] Goh, C. (1998). How ESL learners with different listening abilities use comprehension strategies and tactics. Language teaching Research, 2, 124-147.

[17] Goh, C. C. M. (2002). Exploring listening comprehension tactics and their interaction patterns. System, 30, 185-206.

[18] Mokhtari, K., \& Reichard, C. (2002). Assessing students' metacognitive awareness of reading strategies. Journal of Educational Psychology, 94, 249-259.

[19] Morley, J. (1999). Current perspectives on improving aural comprehension. ESL Magazine, 2(1), 16-19.

[20] Nguyen, N. Q., \& Thai, C. D. (2017). Listening comprehension: First-year

[21] Oppenheim, A. N. (1992). Questionnaire design, interviewing attitude measurement. London: Continuum.

[22] Osada, N. (2004). Listening comprehension research: A briefreview of the past thirty years. Dialogue, 3, 53-66.

[23] Oxford, R. L. (1990). Language learning strategies: What every teacher should know. New York: Newberry House.

[24] Palmer, D. J., \& Goetz, E. T. (1988). Selection and use of study strategies: The role of the studier's beliefs about self and strategies. In C. E. Weinstein, E. T. Goetz, \& P. Alexander (Eds.), Learning and study strategies: Issues in assessment, instruction, and evaluation (pp. 77- 100). Orlando, FL: Academic Press.

[25] Peterson, P. (2001). Skills and strategies for proficient listening. In M. Celce-Murcia (Ed.), Teaching English as a second or foreign language (pp. 87-110). Boston: Heinle \& Heinle

[26] Radhakrishna, R. B. (2007). Tips for developing and testing questionnaires/instruments. Journal of Extension, 45(1). Retrieved from http://www.joe.org/joe/2007february/tt2.php.

[27] Richards, J. C. (1983). Listening Comprehension: approach, design and procedure. TESOL Quarterly, 17(2), 219-249.

[28] Richards, J. C. (2008). Teaching listening and speaking: from theory to practice. Cambridge: Cambridge University Press.

[29] Robin, B. (2012). An introduction to statistics correlation. Retrieved in January 2019 from http://www. floppybunny.org/robin/web/virtualclassroom/stats/basics/part9.pdf

[30] Rost, M. (2002). Teaching and researching listening. London: Longman.

[31] Seliger, H. W., \& Shohamy, E. (1997). Second language research methods. New York: Oxford University Press.

[32] Sharma, D. (2007). Teaching English as a second language. New Delhi: Deep and Deep Pvt. Ltd.

[33] Simasangyaporn, N, (2016). The effect of listening strategy instruction on Thai learners' self-efficacy, English listening comprehension and reported use of listening strategies. Published Dissertation of Doctor of Philosophy, University of Reading, Thailand.

[34] Smith, M. E. (1994). Management research: an introduction. London: Sage.

[35] To, M. T. (2006). Almost Vietnamese teachers of English are just at bachelorlevel. VietNamNet, 1-2. Retrieved fromhttp://www.vnn.vn/giaoduc/tintuc/2006/11/635009/.

[36] Ur, P. (1984). Teaching listening comprehension. Cambridge: Cambridge University Press. 
Correlations between Listening Comprehension Problems Encountered By English Majors and Their Coping Strategies

[37] Vandergrift, L. (1997). The strategies of second language (French) listeners: A descriptive study. Foreign Language Annals, 30(3), 387-409.

[38] Vandergrift, L. (2003). Orchestrating strategy use: towards a model of the skilled L2listener. Language Learning, 53(3), 463-496.

[39] Victori, M., \& Lockhart, W. (1995). Enhancing metacognition in self-directed language learning. System, $23,223-234$.

[40] Yildiz, N., \& Albay, M. (2015). The Role of Listening Skills in Developing Communicative Competence: A Case Study in the Language Classroom. International Journal of Social Sciences \& Educational Studies, 2(2), 4-11.

[41] Zimmerman, B. J., \& Schunk, D. H. (2001). Self-regulated learning and academic achievement. Mahwah, NJ: Erlbaum.

\section{AUTHOR'S BIOGRAPHY}

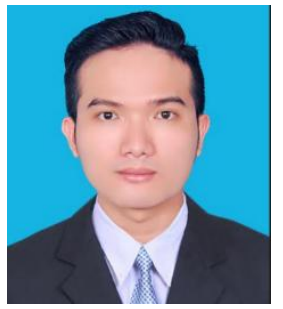

Mr. Chau Thanh Nha, is currently a full-time lecturer of English at Van Lang University (VLU). Besides, he had over two years' experience in teaching English skills to English majors and non-English majors at The Saigon International University from August 2016 to October 2018. More than that, he has been teaching English at Duong Minh Language School for over 4 years. He has extensive experience in working with EFL students of all ages including kids, teenagers and adults. He earned his Master's Degree in English Language at Ho Chi Minh City University of Technology in July 2019. His academic areas of interest mostly lie in TESOL methodology, language skills, and applied linguistics.

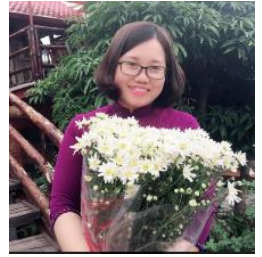

Ms. Hoang Thi Hoa, is currently a full-time lecturer of English at Van Lang University (VLU). She obtained her master's degree in TESOL at University of Languages and International Studies (ULIS), Vietnam National University (VNU), Hanoi. She had over 16 years' experience in teaching English to English majors and non-English majors at Luong The Vinh university and Vocational Training College No.20, MOD. She had the wonderful opportunity to teach a diverse group of students, and as a result, she developed highly effective teaching techniques and instructional methods, which have allowed her to educate all styles of learners. Within her career, she had leadership experience as the Head of Faculty of Foreign Languages at Luong The Vinh university.

Citation: Chau Thanh Nha,M.A., Hoang Thi Hoa,M.A. "Correlations between Listening Comprehension Problems Encountered By English Majors and Their Coping Strategies" International Journal on Studies in English Language and Literature (IJSELL), vol 8, no. 10, 2020, pp. 24-43. doi: https://doi.org/10.20431/23473134.0810004.

Copyright: (c) 2020 Authors. This is an open-access article distributed under the terms of the Creative Commons Attribution License, which permits unrestricted use, distribution, and reproduction in any medium, provided the original author and source are credited. 